\title{
Stress Prevalence in College Students During COVID-19 Pandemics: Evidence from Economics Undergraduates in a Developing Country
}

\author{
Jorge 0. Moreno Treviño*, Jaqueline Hernández Martínez and Alan García Gallegos \\ Universidad Autónoma de Nuevo León, Facultad de Economía, Monterrey, N.L. México
}

*Corresponding author: Jorge O. Moreno Treviño, Universidad Autónoma de Nuevo León, Facultad de Economía,

Monterrey, N.L. México

\begin{abstract}
ARTICLE INFO
Received: 幽 January 28, 2022

Published: 幽 February 02, 2022

Citation: Jorge O. Moreno Treviño, Jaqueline Hernández Martínez, Alan García Gallegos. Stress Prevalence in College Students During COVID-19 Pandemics: Evidence from Economics Undergraduates in a Developing Country. Biomed J Sci \& Tech Res 41(4)-2022. BJSTR. MS.ID.006624.
\end{abstract}

Keywords: Mental Stress; University Student; Mental Health

\section{ABSTRACT}

Objective: This article analyzes the difference in academic stress levels between generations of the Faculty of Economics of the Autonomous University of Nuevo León (UANL) in the context of the COVID-19 pandemic.

Method: A stratified random sample at the Faculty of Economics, UANL, representative by semester and sex strata, is constructed $(n=350)$. The SISCO Inventory of Academic Stress is applied, and the analysis is done using the mean difference of stress levels between first-year students and older generations.

Results: The results show that students that started their university studies with online lectures during the pandemic are more likely to have moderate academic stress levels. In contrast, students who experienced face-to-face learning are more likely to have strong academic stress levels.

Discussion: These results are fundamental to developing psycho-social interventions for this population.

\section{Introduction}

On December 31, 2019, the Wuhan Municipal Health Commission reported a cluster of pneumonia cases caused by a new coronavirus. As of March 11, 2020, the WHO determines COVID-19 as a pandemic due to the disease's levels of spread and severity. On March 14, 2020, the Secretary of Public Education, Esteban Moctezuma, reported on suspending primary and upper secondary school classes. By March 30, Mexico enters a health emergency, and new measures against the coronavirus are announced, including the suspension of non-essential activities. Studies show that a long period of confinement during a pandemic can negatively affect children's physical and mental health [1]. Furthermore, university students appear to be particularly susceptible to the adverse effects of quarantine [2]. Learning through online platforms has given rise to depressive and anxiety disorders among university students [3]. The fact that students face various challenges when entering university is added. Authors such as Martínez-Otero and Torres (2005) mention that academic work and time dedicated to studying can affect the students or generate concerns. The objective of this study is to analyze the difference in academic stress levels among first-year students of the Bachelor of Economics of the Faculty of Economics of the Autonomous University of Nuevo León (FAECO-UANL), who began their university studies virtually, and the generation that experienced classes face-to-face before the COVID-19 pandemic. This methodology permits identifying the possible impact of starting university studies on students' mental health during the pandemic. 


\section{Background}

Rivas Espinosa, et al. [4] find that the level of academic stress between groups of students who studied the semester with online lectures and face-to-face classes is different, being moderately high in the first group. Acevedo, et al. [5] show that students who took the semester online presented more severe manifestations of stress, anxiety, and depression. Among the stressors presented by students during the COVID-19 pandemic are the overload of tasks and the work that must be completed within the deadlines established by teachers [6], the resolution of online exams, academic work deadlines and waiting for a teacher's response [7]. Lovón, et al. [8] analyze the repercussions of the COVID-19 quarantine on the mental health of two groups of students: one with adequate technological resources and the other lacking quality technologies, finding that the main consequence for the first group is the stress due to academic overload, while for the second group, in addition to stress, they result in frustration and university dropout.

\section{Method}

\section{Participants}

The sample design framework was created considering the representative university student in the total population of the Faculty of Economics at UANL as the unit of study. For this purpose, an unrestricted random sample was designed, stratified in two dimensions: semester of study (first, third, fifth, seventh, and ninth semesters) and gender (male and female), giving a total of 10 classification strata. Thus, the student composition of the FAECOUANL for the semester August-January 2020-2021 was taken as a database. Therefore, the composition observed in Table 1 was considered as the target population.

Table 1: Composition of target population: economics students, FAECO-UANL.

\begin{tabular}{|c|c|c|c|}
\hline Semester & Female & Male & Total \\
\hline 1 & 45 & 103 & 148 \\
\hline 3 & 34 & 52 & 86 \\
\hline 5 & 28 & 67 & 95 \\
\hline 7 & 38 & 47 & 85 \\
\hline 9 & 21 & 28 & 49 \\
\hline Total & 166 & 297 & 463 \\
\hline
\end{tabular}

\section{Data}

The data presented in this research work comes from a survey prepared with a set of instruments that allow knowing: the student's cognitive abilities, vocational academic aptitudes, socioeconomic, family and home context, consumption habits, and metrics of selfconcept perfectionism and multiple intelligences.

\section{Instruments}

Socioeconomic questionnaire. The instrument consists of six parts: identification data, personal data, housing data, domestic equipment, scholarship program and resources to carry out the studies. In addition, questions related to the place of study, privacy at the time of studying, as well as questions about the previous knowledge of the faculty and opinions about studying economics were included, which were written by Brenda Medina (psychologist of the Faculty of Economics, UANL). SISCO Inventory of Academic Stress [9]. This instrument recognizes the stress characteristics that usually accompany upper secondary, higher, and postgraduate students during their studies [10]. It is made up of 45 items, 15 for each of the three dimensions of academic stress: stressors, symptoms, and coping strategies, to measure students' academic stress. Academic stress is classified into 5 levels: very low stress levels (.01 to 1 ), low stress levels (1.01 to 2), moderate stress levels (2.01 to 3 ), strong stress levels (3.01 to 4 ) and very strong stress levels (4.01 to 5) of academic stress. The response scale has six values: never, hardly ever, rarely, sometimes, almost always, and always, to indicate the frequency with which stressors, symptoms, and coping strategies occur.

\section{Procedure}

Brenda G. Medina Soto, the psychologist from the Faculty of Economics, oversaw the application of questionnaires and the design of the informed consent that the students had to sign before answering. The questionnaires were administered virtually with prior authorization from the Directorate of the Faculty of Economics during October and November 2020. Multiple application sessions were held via the Microsoft Teams platform. Participation was entirely voluntary and anonymous. The importance of answering honestly was highlighted to the students and the fact that the data would be treated confidentially by the psychologist of the Faculty of Economics.

\section{Results}

Table 2 shows the means and mean differences of each level of academic stress, according to whether the student started their university studies during the pandemic (this means first-year students that started with online classes) or if they experienced face-to-face classes before the pandemic (older generations). The Table 3 shows that first-year students are $14.19 \%$ more likely to experience moderate stress levels than older generations. On the other hand, older generations are $14.63 \%$ more likely to experience intense stress than first-year students.

- Each column presents the sample mean of each variable conditional on whether the student began their university 
studies virtually or if the student experienced classes face-toface before the COVID-19 pandemic, and the mean difference.

- The third column shows the difference in means corresponding to the test (Student's t) of differences with unknown and different variance.

- In variables of the dichotomous type $(1=$ Yes $0=$ No), the interpretation of the average is the percentage of declared response: for example, 0.78 is interpreted as $78 \%$ of affirmative response.

- The statistical significance indicators of the statistical test (p-value) are: [a] p<0.10, [b] p <0.05, [c] p <0.01, [d] p <0.001. Source: Own estimation.

Table 2: Sample composition by stratified random unrestricted design: students surveyed by semester and gender.

\begin{tabular}{|c|c|c|c|}
\hline Semester & Female & Male & Total \\
\hline 1 & 35 & 59 & 94 \\
\hline 3 & 29 & 39 & 68 \\
\hline 5 & 26 & 48 & 74 \\
\hline 7 & 32 & 36 & 68 \\
\hline 9 & 20 & 26 & 46 \\
\hline Total & 142 & 208 & 350 \\
\hline
\end{tabular}

Table 3: Means and differences in means between first year students and older generations.

\begin{tabular}{|c|c|c|c|c|}
\hline & $\begin{array}{c}\text { Older } \\
\text { generations }\end{array}$ & $\begin{array}{c}\text { First year } \\
\text { students }\end{array}$ & Difference & \\
\hline Very low stress level & 0.005682 & 0 & 0.005682 & \\
\hline Low stress level & 0.07955 & 0.08989 & -0.01034 & \\
\hline $\begin{array}{c}\text { Moderate stress } \\
\text { level }\end{array}$ & 0.3750 & 0.5169 & -0.1419 & {$[\mathrm{~b}]$} \\
\hline $\begin{array}{c}\text { Strong stress level } \\
\text { Very strong stress } \\
\text { level }\end{array}$ & 0.5170 & 0.3708 & 0.1463 & {$[\mathrm{~b}]$} \\
\hline Sample size: $\mathrm{n}$ & 265 & 0.02247 & 0.0002554 & \\
\hline
\end{tabular}

\section{Conclusion}

This study analyzes the difference in academic stress levels between generations of the Faculty of Economics of the Autonomous University of Nuevo León (UANL) in the context of the COVID-19 pandemic. The results show that students that started their university studies with online lectures during the pandemic are more likely to have moderate academic stress levels. In contrast, students who experienced face-to-face learning are more likely to have strong academic stress levels. This suggests that older generation students present a higher level of academic stress, possibly caused by the transition from face-to-face to virtual education. However, one limitation of the study is that there is no information regarding the mental health situation of students prior to the pandemic, so it cannot be concluded that there has been a change in the levels of stress as consequence of confinement. In addition, the results are limited to the student population of the Faculty of Economics, so they cannot be generalized to the student population in general. Finally, Dewi, et al. [11] show that implementing teaching materials to develop coping strategies to manage stress during the pandemic becomes beneficial for students. Therefore, it is recommended that counseling be strengthened for students regarding stress management and the possibility of receiving professional support from a psychologist. Teachers should also consider offering virtual office hours and supporting students to process and address academic concerns [12-16].

\section{Acknowledgement}

The authors are grateful for Brenda G. Medina Soto's support, the psychologist from the Faculty of Economics who collaborated in selecting instruments and applying the questionnaires. The authors appreciate the support of Dr. David Hernández Barajas, who provided the funding for the application of instruments for the questionnaires. Likewise, the authors appreciate the facilities granted by the Directorate of the Faculty of Economics of the UANL to realize this study. The results are solely the authors' responsibility and do not reflect the position of any binding institution.

\section{References}

1. Guessoum S, Lachal J, Radjack R, Carretier E, Minassian S, et al. (2020) Adolescent psychiatric disorders during the COVID-19 pandemic and lockdown. Psychiatry Research 291: 113264.

2. Wathelet M, Duhem S, Vaiva G, Baubet T, Habran E, et al. (2020) Factors Associated with Mental Health Disorders Among University Students in France Confined During the COVID-19 Pandemic.

3. Fawaz M, Samaha A (2021) E-learning: Depression, anxiety, and stress symptomatology among Lebanese university students during COVID-19 quarantine. Nursing Forum 56(1): 52-57.

4. Rivas Espinosa JG, Gaona Rivera AM, Pozos Carmona D (2021) Percepción del nivel de estrés en estudiantes universitarios de enfermería entre la modalidad educativa presencial y a distancia. Reencuentro: Educación y COVID 78: 13-32.

5. Acevedo Mena KM, Amador Jiménez DE (2021) Estrés, estrategias de afrontamiento y experiencia académica en estudiantes universitarios en tiempos de pandemia del COVID-19. La experiencia de Nicaragua y Chile. Revista Torreón Universitario 10(27).

6. Luque Vilca OM, Bolivar Espinoza N, Achahui Ugarte VE, Gallegos Ramos JR (2021) Estrés académico en estudiantes universitarios frente a la educación virtual asociada al covid-19. PURIQ 4(1): 56-65.

7. Herrera Corona L, Mendoza Zaragoza NE, Buenabad Arias Ma (2009) Educación a distancia: una perspectiva emocional e interpersonal. Apertura 9(10): 62-77.

8. Lovón Cueva M, Cisneros Terrones S (2020) Repercusiones de las clases virtuales en los estudiantes universitarios en el contexto de la cuarentena por COVID- 19: El caso de la PUCP. Propósitos y Representaciones 8(3). 
9. Barraza Macías A (2018) INVENTARIO SISCO SV-21. Inventario SI Stémico COgnoscitivista para el estudio del estrés académico.

10. Barraza Macías A (2007) El Inventario SISCO del Estrés Académico. Investigación Educativa Duranguense 7: 90-93.

11. Dewi R, Dalimunthe RZ, Asiah Matondang I, Sianipar EL, Dalimunthe MB (2021) Learning Material Development as A Coping Strategy for Managing Student Stress During the Pandemic. Journal of Social Sciences 4(3): 28-34.

12. Zhai Y, Xue Du (2020) Addressing collegiate mental health amid COVID-19 pandemic. 288: 113003

ISSN: 2574-1241

DOI: $10.26717 /$ BJSTR.2022.41.006624

Jorge 0 MorenoTreviño. Biomed J Sci \& Tech Res

(c) (P) This work is licensed under Creative Commons Attribution 4.0 License

Submission Link: https://biomedres.us/submit-manuscript.php
13. Martínez Otero V, Torres L (2005) Análisis de los hábitos de estudio en una muestra de alumnos universitarios. Revista Iberoamericana de Educación 36(7).

14. (2020) Organización Mundial de la Salud. Covid-19: cronología de la actuación de la OMS.

15. (2020) Secretaría de Gobernación. Diario Oficial de la Federación. Acuerdo número.

16.(2020) Secretaría de Gobernación. Diario Oficial de la Federación. Acuerdo por el que se establecen acciones extraordinarias para atender la emergencia sanitaria generada por el virus SARS-Cov2.

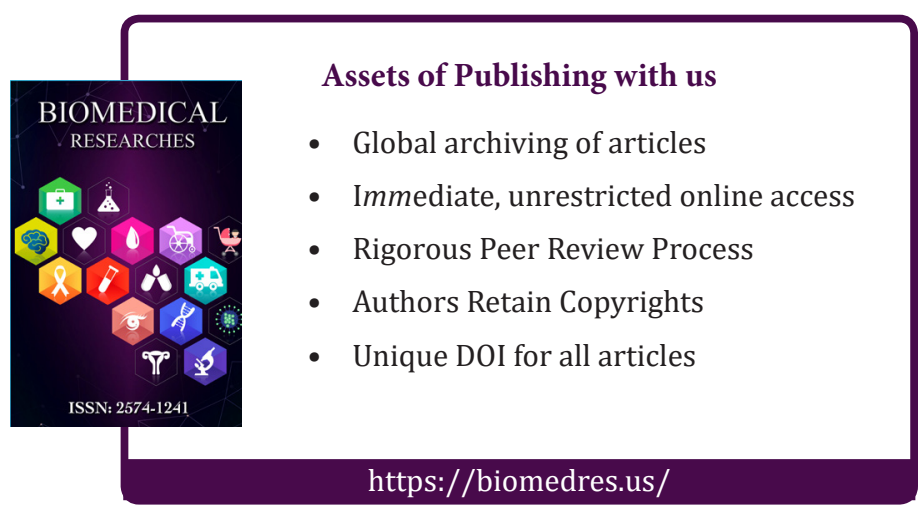

